\title{
Dynamic Behavior of Gas Nano-sized Bubbles in Liquid Phase of the Metal being Electrodeposited
}

\author{
O.B. Girin*, I.M. Kuzyayev
}

\author{
Ukrainian State University of Chemical Technology, 8, Gagarin Ave., 49005 Dnipropetrousk, Ukraine
}

(Received 27 January 2016; revised manuscript received 04 March 2016; published online 15 March 2016)

\begin{abstract}
The paper deals with the experimental results which confirm the occurrence of foam on the crests of waves of metals being electrodeposited in the course of their wavelike flow under action of the external force of insignificant value directed parallel to the crystallization front. The mechanism of foam formation on the crests of waves of metals being electrodeposited, conditioned by the dynamic behavior of gas nanosized bubbles in the liquid phase of the metal being electrodeposited, is offered. The paper also presents the mathematical models for analysis of the dynamic behavior of gas nano- and micro-sized bubbles in the Newtonian and power-law liquids. Results of calculations on obtained mathematical models with the use of MathCAD package are given.
\end{abstract}

Key words: Modeling, Gas bubble, Metallic liquid, Foam, Metal being electrodeposited.

DOI: 10.21272/jnep.8(1).01034

PACS numbers: 51.10. + y, 61.25.Mv, 81.15.Pq

\section{INTRODUCTION}

Many works [1-9] deal with the experimental study of structural features of electrodeposited metals and alloys. The existence of phenomenon of phase formation via a stage of overcooled liquid state in metals being electrodeposited has been confirmed by experimental data in reports [7-9].

One of numerous facts proving the existence of this phenomenon is the established effect of wavelike flow of the surface layers of metals being electrodeposited under action of the external force of insignificant value directed parallel to the crystallization front [9]. This wavelike flow of metals being electrodeposited is accompanied by wave bending around the mechanical obstructions and occurrence of foam on the wave crests [9].

The work [10] represents mathematical modeling of the process of wavelike flow of surface layers of the metal being electrodeposited under action of the external force parallel to the crystallization front. It is found that liquid phase of the metal being electrodeposited is the power-law liquid with the definite values of the consistency coefficient and index of power [10].

The task consisted in modeling of the dynamic behavior of gas nano-sized bubbles in the liquid phase of metal being electrodeposited, which caused occurrence of the foam on wave crests.

\section{BASIC PREREQUISITES OF MATHEMATI- CAL MODELING}

\subsection{Description of the Object and Methods of the Experimental Research}

Centrifugal force has been chosen as an external force of insignificant value, acting parallel to the crystallization front of the metal being electrodeposited. Copper and nickel electrodeposited in the field of the centrifugal force at small overloads (from $35 \mathrm{~g}$ to $314 \mathrm{~g}$ ) served as the model metals.

Structural features of the centrifuge and electro- chemical cells completely excluded an opportunity of electrolyte movement relative to cathode in the process of metal electrodeposition. When the centrifuge worked, cells rotated together with the rotor staying in horizontal position. Cathode was fixed in the cell parallel to its axis thus providing the force action onto the metal being electrodeposited parallel to the crystallization front.

Surface morphology of electrodeposited metals was studied by method of scanning electron microscopy with the use of the mode of image formation in the secondary electrons.

\subsection{Experimental Validation of the Foam Occur- rence}

Fig. 1 shows the sections of crests of solidified waves on the surface of electrodeposited samples of nickel and copper containing solidified foam. The detected foam appears as glass-like formations of various configurations, poorly adherent to the base. For example, Fig. 1a represents the sections of the nickel deposit wave crests with partially detached fragments of solidified foam because of its cracking. Solidified foam on the crest of wave of the copper deposit assumed the waveform (see Fig. 1b).

Obtained experimental results confirm previously observed [9] occurrence of foam on the crests of waves of metals being electrodeposited in the course of their wavelike flow under action of the external force of insignificant value directed parallel to the crystallization front.

The established fact of the foam occurrence on the crests of waves of metals being electrodeposited under external force action proves the dynamic behavior of the smallest gaseous bubbles in metallic liquid. The product of such dynamic interaction of gaseous bubbles and metallic liquid is the foam which occurrence can be explained as follows.

2.3 Mechanism of Foam Formation on the Crests of Waves in Metals being Electrodeposited

* girin@ua.fm 
It is known that phase formation in metals being electrodeposited occurs in the saturated medium of hydrogen even at relatively high current efficiency. For example, when the copper current efficiency is equal to $81 \%$, the volume of hydrogen evolving on the cathode in the course of its electrodeposition exceeds the volume of copper being electrodeposited 749 times. If the copper current efficiency increased to $94 \%$, the ratio of volumes of hydrogen and copper became lower, but remained still significant, equal to 198. Therefore, despite the fact that metals under study were obtained with the current efficiency close to $100 \%$, their phase formation occurred in the hydrogen medium.

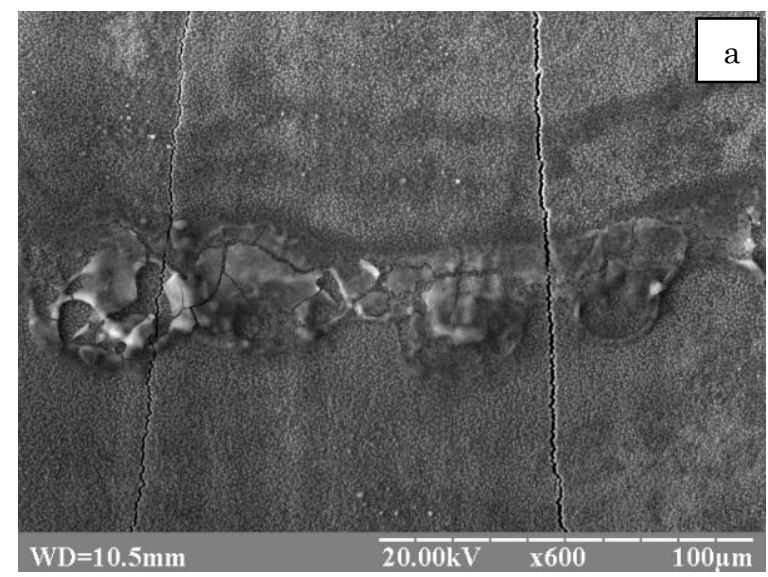

Since the phase formation of the metal being electrodeposited occurs via a stage of overcooled liquid state [7-9], because of high difference in the solubility of hydrogen in the liquid and solid phase, metal solidification is accompanied by release of hydrogen. Being evolved from the solidifying metal, hydrogen bubbles interact with the liquid metallic layers constantly regenerating in the process of electrodeposition and staying in motion under action of the external force.

As a result of this dynamic interaction, hydrogen is redistributed in the metallic liquid medium, which causes the foam formation.

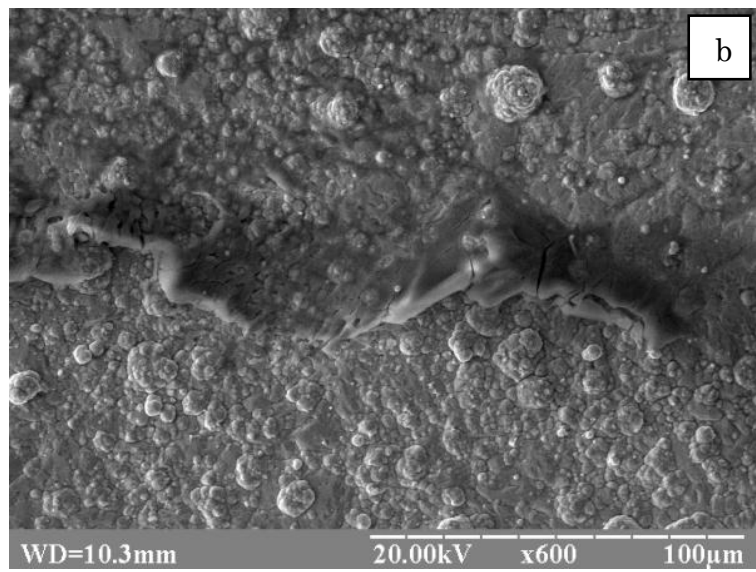

Fig. 1 - SEM images of nickel (a) and copper (b) electrodeposits illustrating the sections of solidified foam on the crests of waves. The force proportional to the acceleration of $35 \mathrm{~g}$ (a) and $314 \mathrm{~g}$ (b) is directed downwards

\subsection{Description of Conditions and Methods of Mathematical Modeling}

Taking into account significant viscosity of the metallic liquid it is expected that formation of the foam on the crests of waves is possible in the event of movement of hydrogen bubbles of extremely small size (about several dozens of nanometers). Consequently, modeling of the dynamic state of two-phase liquid-gas systems was carried out for nano-sized bubbles.

For comparison we considered the similar state of two-phase liquid-gas systems for gas bubbles of size of several dozens of micrometers. Modeling was carried out for the Newtonian and power-law liquids.

Mathematical modeling was performed using differential equations of motion, describing the conservationof-momentum law and continuity equation describing the law of conservation of mass [11-13]. To solve the differential equations in the obtained mathematical models, we used the relevant software product from the MathCAD package.

\section{CONSTRUCTION OF MATHEMATICAL MODELS FOR ANALYSIS OF TWO-PHASE LIQUID-GAS SYSTEMS}

The basic equations used in modeling of the processes in the liquid media are the motion equations. These equations in the projections on the axis are greatly varying in the form and number of members depending on the coordinate system, in which a specific technological process is modeled.
In construction of the mathematical model for analysis of gas bubbles' dynamic behavior in the liquid media we use the spherical coordinate system. As a basic expression, under the assumptions made, motion equation is taken as follows $[14,15]$

$$
\rho \cdot\left(\frac{\partial V_{r}}{\partial t}+V_{r} \cdot \frac{\partial V_{r}}{\partial r}\right)=-\frac{\partial P}{\partial r}+\frac{1}{r^{2}} \frac{\partial}{\partial r}\left(r^{2} \cdot \sigma_{r r}\right)-\frac{\sigma_{\phi \phi}+\sigma_{\theta \theta}}{r}
$$

where $\rho$-density of the liquid medium, $V_{r}$ - radial component of the rate of travel of gas bubble skin, $t, r$ - independent variables (accordingly, time and radial coordinate), $P$ - pressure in the liquid, $\sigma_{r r}, \sigma_{\varphi \varphi}, \sigma_{\theta \theta}$ - stress tensor components.

Continuity equation shall be written as

$$
\frac{\partial}{\partial r}\left(r^{2} \cdot V_{r}\right)=0
$$

Expression for the radial speed on the bubble surface can be represented as follows

$$
V_{r=R_{p}}=\frac{d R_{p}}{d t}
$$

where $R_{p}$ - bubble radius.

Considering the last two expressions, the following dependencies can be written

$$
V_{r}=\frac{R_{p}^{2}}{r^{2}} \frac{d R_{p}}{d t}
$$




$$
\frac{d V_{r}}{d r}=-2 \frac{R_{p}^{2}}{r^{3}} \frac{d R_{p}}{d t}
$$

By substituting expressions (4) and (5) in the motion equation (1), we get

$$
\begin{aligned}
& \rho\left[\frac{d^{2} R_{p}}{d t^{2}} \frac{R_{p}^{2}}{r^{2}}+\left(\frac{d R_{p}}{d t}\right)^{2} \frac{2 R_{p}}{r^{5}}\left(r^{3}-R_{p}^{3}\right)\right]= \\
& =-\frac{\partial P}{\partial r}+\frac{\partial \sigma_{r r}}{\partial r}+\frac{2\left(\sigma_{r r}-\sigma_{\theta \theta}\right)}{r}
\end{aligned} .
$$

Expression (6) is written taking into account the equation $\sigma_{\varphi \varphi}=\sigma_{\theta \theta}$.

Making the integration in equation (6) on the coordinate $r$ within the limits from $r=R_{p}$ to $r=\infty$ and assuming the condition $\sigma_{r r}=-2 \sigma_{\theta \theta}$, we get the expression

$$
\begin{aligned}
& \rho\left[R_{p} \frac{d^{2} R_{p}}{d t^{2}}+\frac{3}{2}\left(\frac{d R_{p}}{d t}\right)^{2}\right]= \\
& =P\left(R_{p}\right)-P(\infty)+\sigma_{r r}(\infty)-\sigma_{r r}\left(R_{p}\right)+3 \int_{R_{p}}^{\infty} \frac{\sigma_{r r}}{r} d r
\end{aligned}
$$

Balance of forces on the liquid-bubble boundary surface (taking into account the action of pressure of the liquid medium onto gas bubble) will satisfy the equation

$$
-P\left(R_{p}\right)+\sigma_{r r}\left(R_{p}\right)=-P_{g}+\frac{2 \sigma}{R_{p}}+P(t),
$$

where $P_{g}$ - pressure inside the bubble, $\sigma$ - surface tension, $P(t)$ - pressure in the liquid medium, i.e. external pressure with regard to the bubble.

Besides, it is possible to write the boundary relation as

$$
-P(\infty)+\sigma_{r r}(\infty)=-P_{\infty},
$$

where $P_{\infty}$ - terminal pressure in the bubble which in many cases can be assumed equal to the atmospheric pressure $\left(P_{\infty}=0.1013 \mathrm{MPa}\right)$ (this value is also referred to as the static pressure in the liquid).

The pressure inside the bubble depends on a number of parameters and, first of all, on the initial pressure in the bubble and pressure in its surrounding liquid. Obviously, any change in the bubble radius also influences the pressure redistribution inside it.

Based on the Fick's second law (taking the Henry's law into account) and the equation of condition for the ideal gas, we get the equation below

$$
\begin{aligned}
& \frac{d P_{g}}{d t}=-\frac{3 P_{g}}{R_{p}} \cdot \frac{d R_{p}}{d t}+\frac{6 \rho^{2} \cdot D \cdot R_{p} \cdot(R \cdot T)^{2}}{M^{2}} \times \\
& \times \frac{\left(K_{p} \cdot P_{g 0}-K_{p} \cdot P_{g}\right)^{2}}{\left(P_{g} \cdot R_{p}{ }^{3}-P_{g 0} \cdot R_{p 0}^{3}\right)}
\end{aligned}
$$

where $D$ - diffusion coefficient, $R$ - universal gas constant, $T$ - temperature, $P_{g 0}$ - initial pressure in the bubble, $K_{p}-$ Henry's diffusion constant, $M$ - molecular weight of gas in the bubble, $R_{p 0}$ - initial radius of the bubble.
The further construction of the mathematical model depends on the type of liquid used in modeling of these processes, that is, on the rheological equation to be chosen.

If the liquid medium surrounding gas bubble would have the characteristics of the Newtonian liquid, relation between the components of stress tensor $\sigma_{i j}$ and components of tensor of strain rates $d_{i j}$ can be represented as

$$
\sigma_{i j}=2 \eta_{0} \cdot d_{i j}
$$

where $\eta_{0}$ - viscosity coefficient.

Based on the rheological equation for the Newtonian liquid (11) and ratios (8) and (9), the motion equation (7) takes on the form

$$
\begin{aligned}
& \rho\left[R_{p} \frac{d^{2} R_{p}}{d t^{2}}+\frac{3}{2}\left(\frac{d R_{p}}{d t}\right)^{2}\right]= \\
& =P_{g}-\frac{2 \sigma}{R_{p}}-\frac{4 \eta_{0}}{R_{p}} \frac{d R_{p}}{d t}-P_{\infty}-P(t)
\end{aligned}
$$

When modeling the processes in the liquid media, it is necessary to reckon with various effects. One of such effects is the viscosity anomaly, that is, viscosity change depending on strain rate. In this case, usage of the rheological equation of condition for the Newtonian liquid (11), and hence the equation (12), in many cases results in significant errors. The most adequate results in this case are shown by the power-law liquid, for which the expression below is true

$$
\sigma_{i j}=2 \cdot \mu \cdot\left|4 \cdot I_{2}\right|^{(n-1) / 2} \cdot d_{i j},
$$

where $n$ - index of power; $\mu$ - consistency coefficient; $I_{2}$ - the second invariant of strain rates' tensor.

From the last equation, taking into account the expressions (2)-(5), the radial component of the stress tensor can be represented as follows

$$
\sigma_{r r}=-\frac{4 \cdot \mu \cdot R_{p}^{2 n}}{r^{3 n}} \cdot\left|\frac{d R_{p}(\tau)}{d t}\right|^{n-1} \cdot \frac{d R_{p}(\tau)}{d t} .
$$

Substitution of (14) instead of (11) in the motion equation (7) results in the ratio

$$
\begin{aligned}
& \rho\left[R_{p} \frac{d^{2} R_{p}}{d t^{2}}+\frac{3}{2}\left(\frac{d R_{p}}{d t}\right)^{2}\right]= \\
& =P_{g}-\frac{2 \sigma}{R_{p}}-\frac{4 \cdot \mu}{n \cdot R_{p}^{n}} \cdot\left|\frac{d R_{p}}{d t}\right|^{n-1} \cdot \frac{d R_{p}}{d t}-P_{\infty}-P(t)
\end{aligned}
$$

When it is necessary to specify the processes occurring in the technical systems with abnormal effect (both of viscous parameters and elastic behavior of the liquid media), other rheological equations can be used [11].

Developed mathematical models can also be used in modeling of the processes and for the other technological systems, that is: in obtaining of the foamed polymeric composites, analysis and optimization of the cavitation phenomena etc. 


\section{RESULTS OF CALCULATIONS ON OBTAINED THEORETICAL DEPENDENCIES}

\subsection{Modeling of Dynamic Behavior of Gas Nano- sized Bubble in the Newtonian Liquid}

Results of calculations for the system of differential equations (12) and (10) are represented in Fig. 2. General parameters for the calculations are taken as follows: $\quad P_{\infty}=0.1013 \mathrm{MPa} ; \quad M=0.002 \mathrm{~kg} / \mathrm{mol}$; $R=8.314 \mathrm{~J} /(\mathrm{K} \cdot \mathrm{mol}) ; \quad \sigma=0.07 \mathrm{~N} / \mathrm{m} ; \quad \rho=1800 \mathrm{~kg} / \mathrm{m}^{3}$; $T=293 \mathrm{~K} ; \quad K_{p}=4.26 \cdot 10^{-9} \mathrm{~m}^{2} / \mathrm{N} ; \quad D=3.5 \cdot 10^{-9} \mathrm{~m}^{2} / \mathrm{s} ;$ $P(t)=0.182 \mathrm{MPa} ; P_{g 0}=0.426 \mathrm{MPa} ; \eta_{0}=1.98 \cdot 10^{-2} \mathrm{~Pa} \cdot \mathrm{s}$.

Based on the analysis of charts represented in Fig. 2, the following common features of the derived
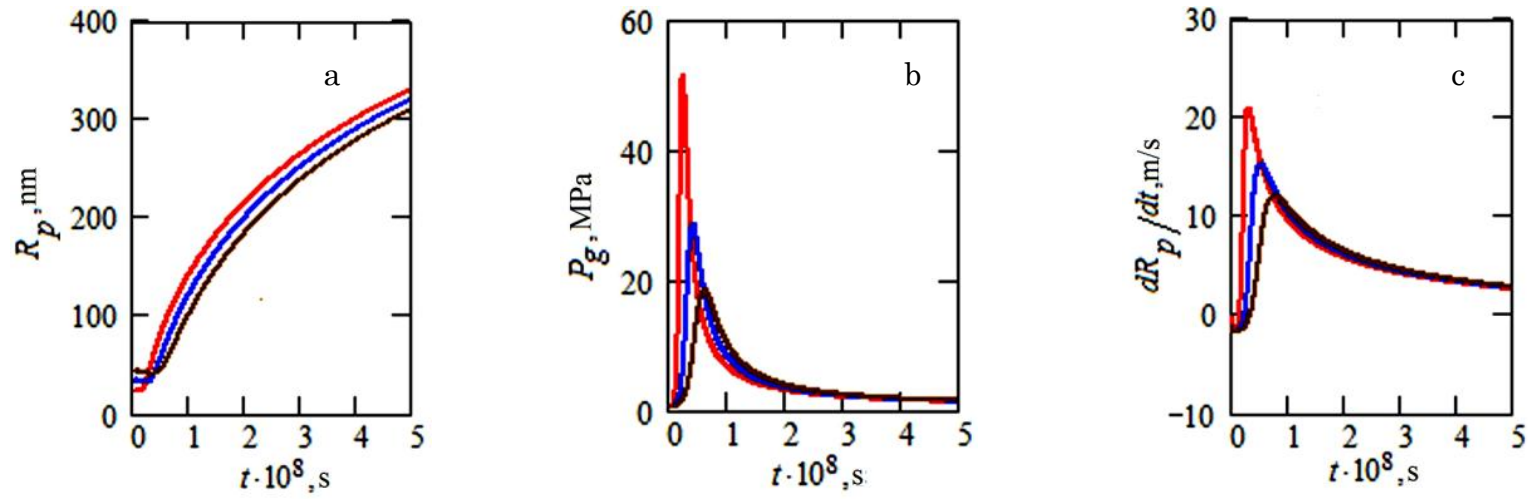

Fig. 2 - Dynamic characteristics of gas nano-sized bubble in the Newtonian liquid in the time interval $t=0 . .5 \cdot 10^{-8} \mathrm{~s}$ : radius (a), internal pressure (b), rate of radius change (c) at different values of its initial radius $\left(-R_{p 0}=25 \mathrm{~nm} ;-R_{p 0}=35 \mathrm{~nm}\right.$; $\left.-R_{p 0}=45 \mathrm{~nm}\right)$
With the further growth of bubble radius to micron size, behavior of the dynamic characteristics undergoes significant changes (see Fig. 3). The major changes compared with Fig. 2 are as follows: firstly, there is the rithmic damping decrement; secondly, internal pressure in the bubble does not exceed the initial pressure over time; thirdly, the less the radius of micron-size bubble, the higher rate of the process of the oscillation damping is observed. The differences revealed can be explained by very significant difference in gas bubble - liquid me-

Let's represent the stiffness of $C_{s}$ system as

$$
C_{s}=\frac{\eta_{0} \cdot P(t) \cdot \sqrt{R \cdot T}}{2 \cdot \pi \cdot R_{p 0} \cdot \rho_{g} \cdot g \cdot \sqrt{M}},
$$

where $\rho_{g}$ - gas density, $g$ - gravity acceleration.

Then the values of stiffness for the system with nano-sized bubbles would be three orders of magnitude higher than stiffnesses for micron-size bubbles. For example, for the parameters: $\eta_{0}=1.98 \cdot 10^{-2} \mathrm{~Pa} \cdot \mathrm{s}$; $P(t)=0.182 \mathrm{MPa} ; \quad R=8.314 \mathrm{~J} /(\mathrm{K} \cdot \mathrm{mol}) ; \quad R_{p 0}=25 \mathrm{~nm} ;$ $T=293 \mathrm{~K} ; \rho g=0.09 \mathrm{~kg} / \mathrm{m}^{3} ; M=0.002 \mathrm{~kg} / \mathrm{mol}$ we shall obtain the value of stiffness $C_{s}=2.869 \cdot 10^{13} \mathrm{~N} / \mathrm{m}$.

\subsection{Modeling of Dynamic Behavior of Gas Nano- sized Bubble in the Power-law Liquid}

\subsection{Modeling of Dynamic Behavior of Gas Micro- sized Bubble in the Newtonian Liquid} clearly expressed wave process with the definite logadium system stiffness values. curves' behavior can be mentioned. Firstly, in the given time interval for the chosen initial values of radii (from $25 \mathrm{~nm}$ to $45 \mathrm{~nm}$ ) the radius of gas bubble gradually increases, with the reduction of rate of the bubble change to the constant value (see Fig. 2a). In this case, the less the initial value of radius, the larger value of the radius will be at the end of the considered interval.

Secondly, the charts for pressure changes inside the bubble (see Fig. 2b) and charts for the rate of change in the bubble radius (see Fig. 2c) feature clearly expressed extremum arising at the initial section of the time interval. Values of extremums grow with the decrease in the initial radius both for pressure-time relationship and the rate function.
Let's consider further the gas bubble behavior in the liquid medium described with the use of the power-law liquid, i.e. calculations are made for the system of equations (15) and (10). Fig. 4 represents the charts which parameters are completely the same with those in Fig. 2. Parameters for the power-law liquid are taken as: $n=0.38 ; \mu=0.0198 \mathrm{~Pa} \cdot \mathrm{s}^{n}$.

As is seen from charts of Fig. 4, behavior of the dynamic characteristics of nano-sized gas bubble for the power-law liquid fundamentally differs from the behavior of its corresponding characteristics for the Newtonian liquid (see Fig. 2).

For all three dynamic characteristics of the gas bubble of nano-sized type, when the power-law liquid is used, oscillating process is observed. The maximums of pressure (see. Fig. 4b) correspond to the minimums of the gas bubble radius (see. Fig. 4a).

Significant difference in the behavior of nano-sized bubbles can be explained by the dependence of viscosity on the shear rate.

\subsection{Modeling of Dynamic Behavior of Gas Micro- sized Bubble in the Power-law Liquid}

Fig. 5 represents the dynamic characteristics of gas micron-size bubbles in the power-law liquid. Comparison of results on graphic charts of Fig. 3 and Fig. 5 proves that no significant differences in the behavior of dynamic characteristics of micron-size gas bubbles, both in the Newtonian liquid and in the power-law liquid, are observed. 

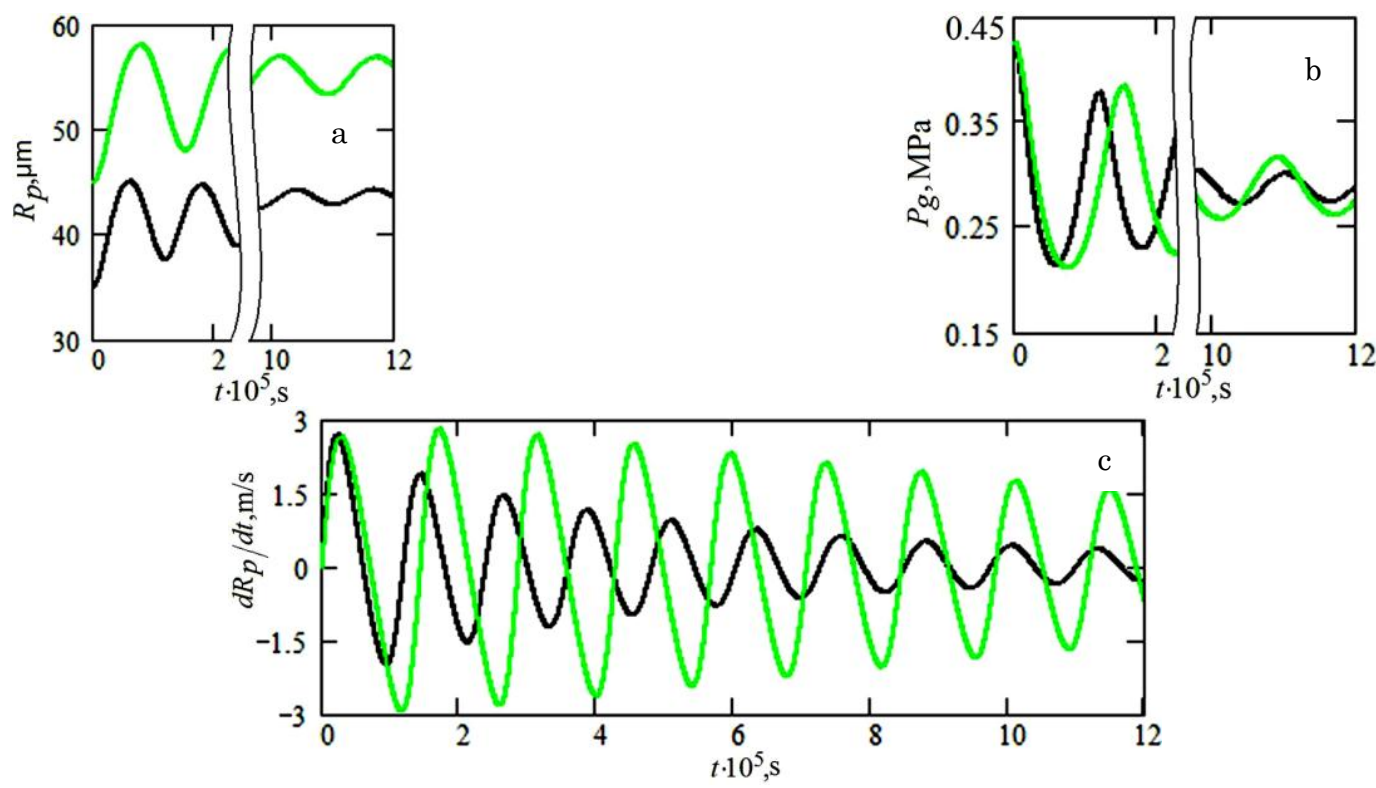

Fig. 3 - Dynamic characteristics of gas micro-sized bubble in the Newtonian liquid in the time interval $t=0 . .12^{\cdot 10^{-5}} \mathrm{~s}:$ radius (a), internal pressure (b), rate of radius change (c) at different values of its initial radius $\left(-R_{p 0}=35 \mu \mathrm{m} ;-R_{p 0}=45 \mu \mathrm{m}\right)$
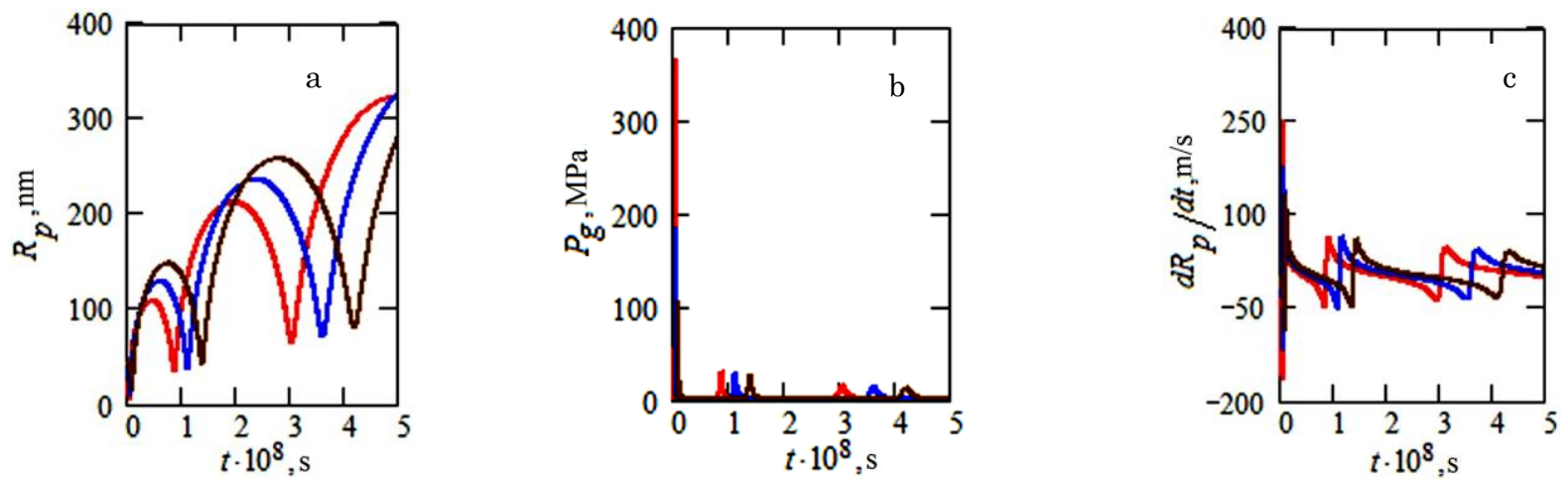

Fig. 4 - Dynamic characteristics of gas nano-sized bubble in the power-law liquid in the time interval $t=0 . .5 \cdot 10^{-8} \mathrm{~s}$ : radius (a), internal pressure (b), rate of radius change (c) at different values of its initial radius $\left(-R_{p 0}=25 \mathrm{~nm}\right.$; $-R_{p 0}=35 \mathrm{~nm}$; $\left.-R_{p 0}=45 \mathrm{~nm}\right)$
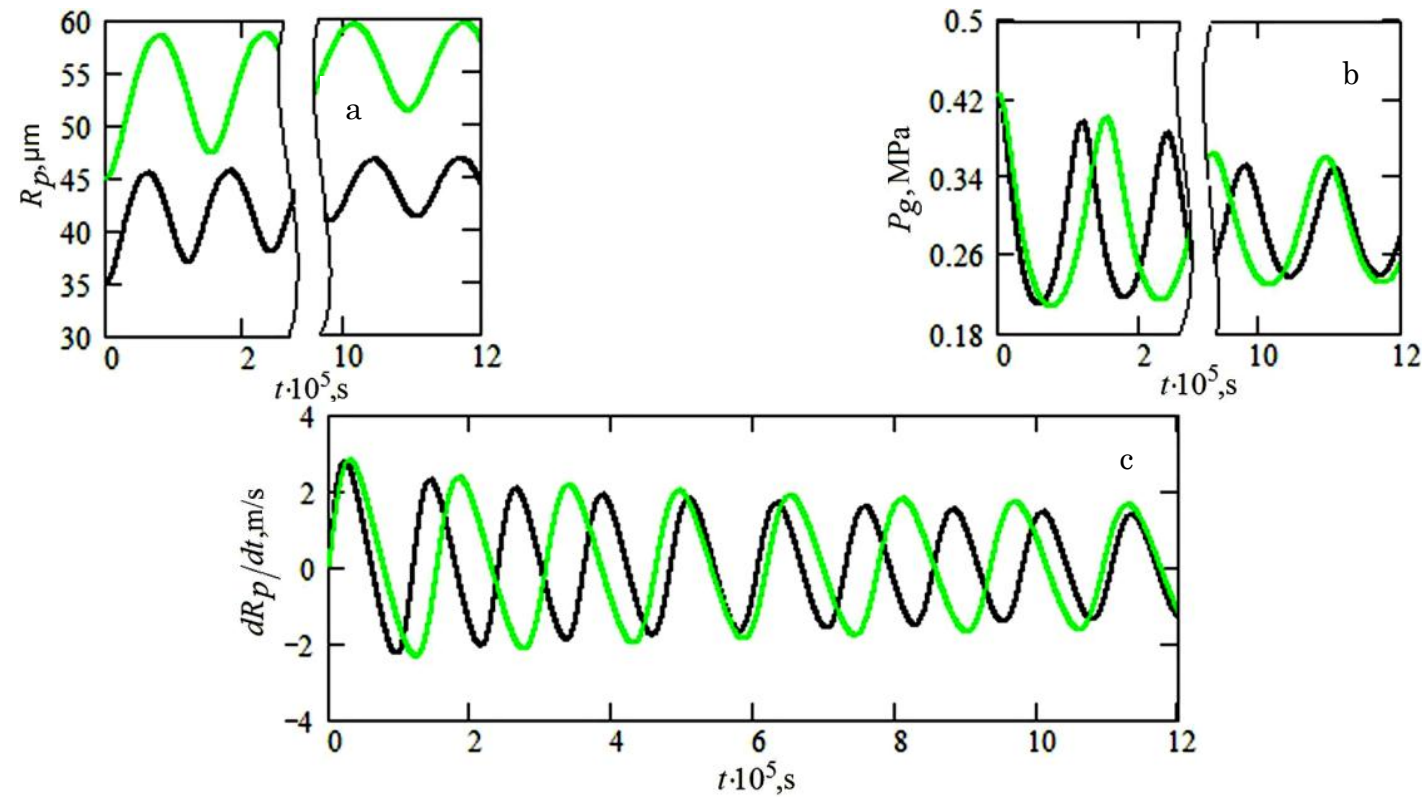

Fig. 5 - Dynamic characteristics of gas micron-size bubble in the power-law liquid in the time interval $t=0 . .12^{\cdot} \cdot 10^{-5} \mathrm{~s}$ : radius (a), internal pressure (b), rate of radius change (c) at different values of its initial radius $\left(-R_{p 0}=35 \mu \mathrm{m} ;-R_{p 0}=45 \mu \mathrm{m}\right)$ 
The last remark confirms that with micron size of gas bubbles the dependence of viscosity on the shear rate has no decisive influence onto dynamic characteristics of gas bubbles, while the stiffness of the system with gas bubbles, which is much less than for nanosized bubbles, has the dominant role.

\section{CONCLUSIONS}

We confirmed the occurrence of foam on the crests of waves of the metals being electrodeposited in the course of their wavelike flow, and offered the mechanism of its formation which is conditioned by the dynamic behavior of gas nano-sized bubbles in the liquid phase of the metal being electrodeposited.

Mathematical models have been developed for the modeling of gas bubbles' dynamic behavior in various types of the liquid media, and software units have been generated to implement the developed mathematical models.

Fundamental differences in the behavior of gas nano-sized and micro-sized bubbles are shown, and the reasons of such differences are given.

\title{
Динамічна поведінка газових нанорозмірних бульбашок у рідкій фазі електроосаджуваного металу
}

\author{
О.Б. Гірін, І.М. Кузяев
}

Украйнський державний хіміко-технологічний університет, пр. Гагаріна, 8, 49005 Дніпропетровськ, Україна

\begin{abstract}
Представлено експериментальні результати, що підтверджують виникнення піни на гребенях хвиль електроосаджуваних металів при їх хвилеподібному плині під дією зовнішньої сили незначної величини, спрямованої паралельно фронту кристалізації. Запропоновано механізм утворення піни на гребенях хвиль електроосаджуваних металів, обумовлений динамічною поведінкою газових нанорозмірних бульбашок у рідкій фазі електроосаджуваного металу. Представлено математичні моделі, що дозволяють проводити аналіз динамічної поведінки газових нано- і мікророзмірних бульбашок у ньютонівській та степеневій рідинах. Наведено результати розрахунків за отриманими математичними моделями з використанням пакету MathCAD.
\end{abstract}

Ключові слова: Моделювання, Газова бульбашка, Металева рідина, Піна, Електроосаджуваний метал.

\section{Динамическое поведение газовых наноразмерных пузырьков в жидкой фазе электроосаждаемого металла}

\author{
О.Б. Гирин, И.М. Кузяев
}

\begin{abstract}
Украинский государственный хилико-технологический университет, пр. Гагарина, 8, 49005 Днепропетровск, Украина
\end{abstract}

\begin{abstract}
Представлены экспериментальные результаты, подтверждаюшие возникновение пены на гребнях волн электроосаждаемых металлов при их волнообразном течении под действием внешней силы незначительной величины, направленной параллельно фронту кристаллизации. Предложен механизм образования пены на гребнях волн электроосаждаемых металлов, обусловленный динамическим поведением газовых наноразмерных пузырьков в жидкой фазе электроосаждаемого металла. Представлены математические модели, позволяющие проводить анализ динамического поведения газовых нано- и микроразмерных пузырьков в ньютоновской и степенной жидкостях. Приведены результаты расчетов по полученным математическим моделям с использованием пакета MathCAD.
\end{abstract}

Ключевые слова: Моделирование, Газовый пузырек, Металлическая жидкость, Пена, Электроосаждаемый металл.

\section{REFERENCES}

1. J.-M. Song, D.-S. Wang, C.-H. Yeh, W.-C. Lu, Y.-S. Tsou, S.-C. Lin, Mat. Sci. Eng. A: Struct. 559, 655 (2013).

2. S. Ghaziof, M.A. Golozar, K. Raeissi, J. Alloy. Compd. 496, 164 (2010).

3. L.D. Rafailovic, D.M. Minic, H.P. Karnthaler, J. Wosik, T. Trisovic, G.E. Naurer, J. Electrochem. Soc. 157, D295 (2010).

4. A.M.P. Sakita, E.C. Passamani, H. Kumar, D.R. Cornejo, C.S. Fugivara, R.D. Noce, A.V. Benedetti, Mater. Chem. Phys. 141, 576 (2013).

5. Z. Zeng, Y. Sun, J. Zhang, Electrochem. Commun. 11, 331 (2009).

6. R.D. Noce, N. Barelli, R.F.C. Marques, P.T.A. Sumodjo, A.V. Benedetti, Surf. Coat. Tech. 202, 107 (2007).

7. O.B. Girin, Mater. Sci. Forum 561-565, 2369 (2007).
8. O.B. Girin, Defect Diffus. Forum 303-304, 99 (2010).

9. O.B. Girin, Int. J. Mater. Sci. 2, 108 (2012).

10. И.М. Кузяев, О.Б. Гирин, Металознавство $m a$ терлічна обробка металів №1, 27 (2015) (I.M. Kuzyaev, O.B. Girin, Metaloznavstvo ta termichna obrobka metaliv No 1, 27 (2015)).

11. R.B. Bird, R.S. Armstrong, O. Hassager, Dynamics of Polymeric Liquids. V. 1. Fluid Mechanics (N.-Y.: Wiley: 1977).

12. G. Bohme, Stromungsmechanik Nicht-Newtonscher Fluids (Stuttgart: B.G. Teubner: 1981).

13. Z. Jing, W. Daming, I.M. Kuzyayev, X. Hong, L. Ying, Int. Polym. Proc. 23, 286 (2008)

14. C.D. Han, H.J. Yoo, Polym. Eng. Sci. 21, 518 (1981).

15. H.J. Yoo, C.D. Han, AIChE J. 28, 1002 (1982). 